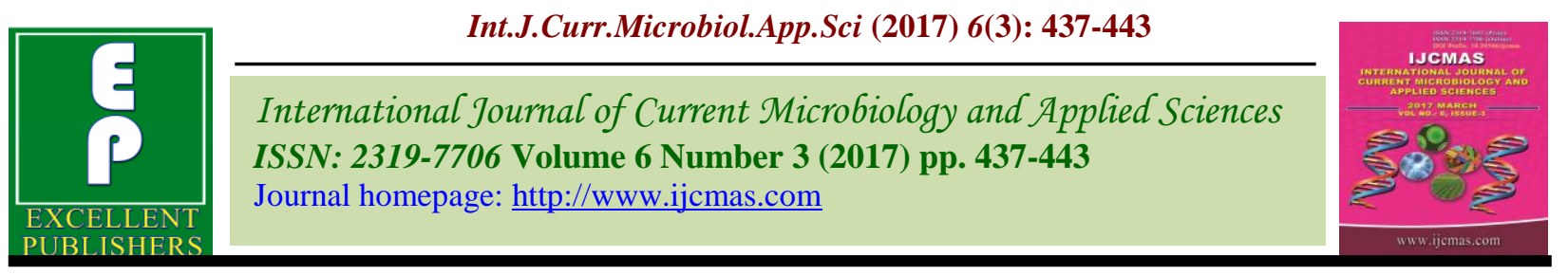

Original Research Article

https://doi.org/10.20546/ijcmas.2017.603.050

\title{
Lipo-Chito Oligosaccharides Enhances Germination Tolerance of Maize to Salinity Stress
}

\author{
D. Udhaya Nandhini* and E. Somasundaram \\ Department of Sustainable Organic Agriculture, Tamil Nadu Agricultural University, \\ Coimbatore-641 003, Tamil Nadu, India
}

*Corresponding author

\begin{tabular}{|c|c|}
\hline & A B S T R A C T \\
\hline $\begin{array}{l}\text { K e y w o r d s } \\
\text { Salinity, Lipo Chito } \\
\text { Oligosaccharides, } \\
\text { Germination } \\
\text { percentage, } \\
\text { Germination stress } \\
\text { tolerance index, } \\
\text { Mean daily } \\
\text { germination, } \\
\text { Phytotoxicity }\end{array}$ & \multirow{3}{*}{$\begin{array}{l}\text { Worldwide salinity is the foremost soil environmental factor adversely } \\
\text { affecting the seed germination, plant growth and yield. Recent studies shows } \\
\text { that Lipo Chito Oligosaccharide (LCO-nod factors) as a unique molecule, } \\
\text { which is responsible for abiotic stress tolerance. Hence a laboratory } \\
\text { experiment was taken up with a sole objective of seed priming with LCO (4 } \\
\mathrm{ml} / \mathrm{kg} \text { ) on maize seedling growth which are exposed to different levels of } \\
\text { salinity }\left(0,2,4,6,8 \text { and } 10 \mathrm{dS} \mathrm{m}^{-1} \text { ) was laid out in a factorial completely }\right. \\
\text { randomized design with four replications. As a result of salinity stress the } \\
\text { seedling characters of maize were negatively influenced. However nod factor } \\
\text { treated maize seeds had relatively higher germination percentage, germination } \\
\text { stress tolerance index and mean daily germination and found to have decreased } \\
\text { phytotoxicity of roots and shoots. Thus seed priming with nod factor (4 ml/kg) } \\
\text { improved the tolerance to salinity at seedling stage of maize by inducing } \\
\text { physiological changes in seeds. }\end{array}$} \\
\hline Article Info & \\
\hline $\begin{array}{l}\text { Accepted: } \\
\text { 10 February } 2017 \\
\text { Available Online: } \\
10 \text { March } 2017\end{array}$ & \\
\hline
\end{tabular}

\section{Introduction}

Salinity is one of the most critical issues in agriculture around the world which affects the $6 \%$ of the total land area of the planet which is approximately 800 million hectares (FAO, 2012). It has adverse effect on seedling growth, by creating an osmotic potential on the rhizosphere of the crop which leads to soil fertility loss.

Maize is one of the most important cereals, which are grown under various environmental conditions of the world. In India, maize is the third most significant cereal after wheat and rice, is grown on about 71 million hectares with a production of 22.26 million tonnes and productivity of $2476 \mathrm{~kg} / \mathrm{ha}$ (Anonymous, 2014). It is being consumed as prime food and commonly feed to the livestock, which is of its increasing importance. Improvement in establishment characteristics of maize has received considerable attention around the world, particularly in salt affected soils. 
Enhancing the tolerance for salinity would be of substantial value for this sensitive crop when grown under saline conditions.

Germination is a very sensitive phase in the crop growth that reduces the water absorption. Saline environment delays germination of seeds as well as the final germination percentage (Zeinali et al., 2002). Increasing the salt concentration not only reduces the germination but also inhibits the seedling establishment. Seed resistance to increased salinity during germination is essential for plant survival in the field, consequently for its further development and high yield performance.

Pre-sowing seed treatments have been shown to enhance stand establishment in non-saline areas (Khan, 1992) and have potential in saline areas as well (Basra et al., 2005). In the past two decades, improving seed germination and seedling emergence under various stress conditions by means of physiological treatments have been investigated intensively. It is thought that the depressive effect of salinity on germination could be related to a decline in endogenous levels of hormones (Debez et al., 2001)). However, incorporation of plant growth regulators during pre-soaking, priming and other pre-sowing treatments in many vegetables crops have improved seed performance under stress conditions.

Seed priming is one of the biochemical methods that enhances seed performance and provides better germination under adverse conditions. One among the biochemical molecule is lipo chitooligosaccharides (Nod factors/LCO), bacteria-to-plant signals, which are produced as the result of plant-microbe interactions. Nod factors are a unique signal molecule which is known to handle adverse environmental conditions and recently considered to have a hormone like substances. Supanjani et al., (2009) used LCO at concentrations of $10^{-8} \mathrm{M}$ and $10^{-10} \mathrm{M}$ and reported that LCOs increased germination speed 8 hours from 58 hours, increased $69 \%$ of total root length, and increased about $30 \%$ of total surface/projected area of the roots in cauliflower. Leaf area, hypocotyl length and seedling weights of cauliflower were not affected by LCO treatment.

At present, research is in progress and information on seedling tolerance of maize to salinity through nod factors (LCO) is inadequate. Although from the agronomical point of view, the most important trait of maize crop submitted to salinity reflect their adaptation at the early crop establishment phase. Hence the present study was planned to furnish the knowledge about the effect of nod factors (LCO) on seedling growth of maize under saline conditions.

\section{Materials and Methods}

To investigate the effects of salinity-mediated seed priming of LCO on maize germination and seedling establishment under saline conditions, with a completely randomized factorial experiment with four replications was carried out in Tamil Nadu Agricultural University, under laboratory conditions. Seeds of maize hybrid CoHM (6) were primed by soaking in LCO @ $4 \mathrm{ml} / \mathrm{kg}$ of seed for $12 \mathrm{~h}$ at room temperature.

The experiment consists of 2 factors such as six salinity levels $\left(\mathrm{T}_{1}-0 \mathrm{dSm}^{-1}, \mathrm{~T}_{2}-2 \mathrm{dSm}^{-1}\right.$, $\mathrm{T}_{3}-4 \mathrm{dSm}^{-1}, \mathrm{~T}_{4}-6 \mathrm{dSm}^{-1}, \mathrm{~T}_{5}-8 \mathrm{dSm}^{-1}$ and $\mathrm{T}_{6}$ - $\left.10 \mathrm{dSm}^{-1}\right)$ and 2 levels of priming $\left(\mathrm{S}_{1^{-}} \mathrm{LCO}\right.$ primed and $\mathrm{S}_{2^{-}}$unprimed seeds). The experiment was carried out in 48 petri dishes that is 24 for LCO primed seeds and 24 for unprimed (Control) seeds. The salinity levels were obtained by dissolving 1.28, 2.56, 3.84, $5.12,6.4 \mathrm{~g}$ of $\mathrm{NaCl}$ in a litre distilled water, respectively. Distilled water $\left(0 \mathrm{dSm}^{-1}\right)$ was used as a control. Seeds were sown on $10 \mathrm{~cm}$ 
dia petridishes, lined with whatman No. 1 filter paper and were supplied with $10 \mathrm{ml}$ of each treatment solution daily. Observations have been made on $14^{\text {th }}$ day of germination.

\section{Measured parameters}

\section{Germination percentage}

The emergence of plumule was taken as index of germination. Initiation and completion of germination was recorded daily. The germination was recorded daily for 14 days and germination percentage calculated using the following formula

Germination percentage $(\%)=$

Number of germinated seeds

Number of total seeds

\section{Germination stress tolerance index (GSTI)}

The germination stress tolerance index (GSTI) was estimated using following formula (Ashraf et al., 2008):

$\mathrm{PI}=\mathrm{nd}_{1}(1.00)+\mathrm{nd}_{2}(0.75)+\mathrm{nd}_{3}(0.50)+\mathrm{nd}_{4}$ $(0.25)$

Where, $\mathrm{nd}_{1}, \mathrm{nd}_{2}, \mathrm{nd}_{3}$ and $\mathrm{nd}_{4}=$ Number of seeds germinated on the $1^{\text {st }}, 2^{\text {nd }}, 3^{\text {rd }}$ and $4^{\text {th }}$ day, respectively. A germination stress tolerance index (GSTI) was calculated in terms of percentage as follows:

GSTI $=($ PI of stressed seeds $/$ PI of control seeds) $\times 100$

\section{Mean daily germination (MDG)}

This is an index of daily germination speed and it was calculated by using the formula

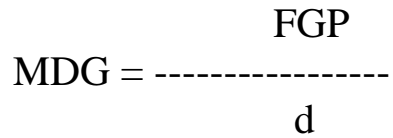

where FGP: final germination percent and $\mathrm{d}$ : test period

\section{Phytotoxicity of roots and shoots}

Phytotoxicity of roots and shoots are calculated based on the following formula

Phytotoxicity of roots and shoots $=$

Shoot/Root length in Control - Shoot/Root length in Stressed

Shoot/Root length in Control

\section{Statistical analysis}

The data on germination percentage was transformed using by arcsine values prior to statistical analysis. Significant differences between treatments were determined using LSD test at the 5 per cent level.

\section{Results and Discussion}

Examination of results showed that both salinity level and priming have significant effects on the aforesaid parameters. Moreover, the interaction of salinity level and priming with lipo chito oligosaccharides (LCO) had significant effect on all seedling parameters tested at 5\% significant level. Priming with LCO relatively increased the germination parameters (germination percentage, mean daily germination) and growth parameters (phytotoxicity of roots and shoots) of maize, under different levels of salt concentrations as compared to non primed seeds.

Data on maize germination percentage showed the effect of LCO priming and non priming at different salinity concentrations. In general germination percentage for both primed and non primed seeds decreased significantly with increasing $\mathrm{NaCl}$ salinity level. However, this reduction was significantly higher for non primed seeds compared to primed seeds (Figure 1). 
Germination percentage (GP) in seed primed with LCO relatively increased compared to the control. Analysis shows the germination percentage in seeds with LCO were 96, 91, $83,73,65$ and 57 for the salinity levels of 0 , $2,4,6,8$ and $10 \mathrm{dsm}^{-1}$.

Germination stress tolerance index (GSTI) was significantly reduced by the induction of salinity stress. However, it varied for the different levels of salinity as shown in figure 1. The highest germination stress tolerance index (GSTI) of 92.4 was noted under $0 \mathrm{dS} \mathrm{m}$ ${ }^{1}$ salinity level and the lowest (46.5) was in 10 $\mathrm{dS} \mathrm{m}^{-1}$. The LCO primed seeds were successful in increasing relatively highest GSTI of 95.2 at $0 \mathrm{dS} \mathrm{m}^{-1}$ while at $10 \mathrm{dS} \mathrm{m}^{-1}$ the GSTI was lower but relative increase was noticed compared to non priming seeds. Among the salinity levels both for priming and non priming, $10 \mathrm{dS} \mathrm{m}^{-1} \mathrm{NaCl}$ level was at the bottom in performing the tolerance.

In general increasing $\mathrm{NaCl}$ concentration will reduce the mean daily germination (Figure 2). The maximum MDG of 6.6 was observed in

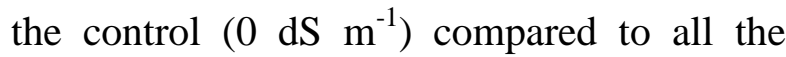
levels of salinity for both LCO primed and non primed seeds. Higher level of salinity inhibits the daily mean germination and registered MDG of 4.09 and 2.23 at $10 \mathrm{dS} \mathrm{m}^{-1}$ for LCO primed and non primed seeds.

The osmotic stress had significant effect on phytotoxicity of roots (PhR) and phytotoxicity of shoots (PhSh) both for LCO primed and non primed seedlings (Figure 3 ). PhR and $\mathrm{PhSh}$ were significantly increased with increasing osmotic stress the lowest values recorded at $0 \mathrm{dS} \mathrm{m} \mathrm{m}^{-1}(0 \%$ and $0 \%$, respectively). The highest value of $\mathrm{PhR}$ (59.1 and 80.7), and PhSh (77.6 and 84.7) observed at $10 \mathrm{dS} \mathrm{m} \mathrm{m}^{-1}$ respectively, for both primed and non primed seeds.

Generally, increasing salinity causes a decrease in maize germination; this might be due to the toxic effects of $\mathrm{Na}^{+}$and $\mathrm{Cl}^{-}$in the process of germination (Khajeh-Hosseini et $a l ., 2003)$. It alters the water imbibitions by seeds due to lower osmotic potential of germination media, causes toxicity which changes the activity of enzymes of alpha amylase activity, nucleic acid metabolism, changes protein metabolism, interrupts hormonal balance, and reduces the utilization of seed reserve food (Gomes-Filho et al., 2002).

Fig.1 Influence of LCO on germination percentage and germination stress tolerance index of maize under salt stress

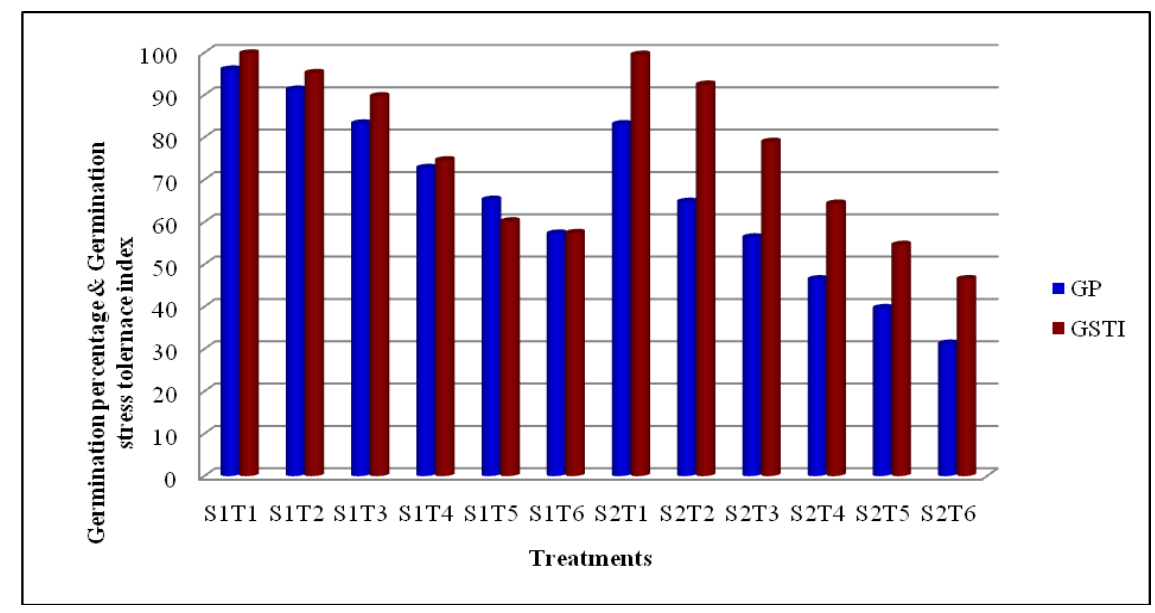


Fig.2 Influence of LCO on mean daily germination of maize under salt stress

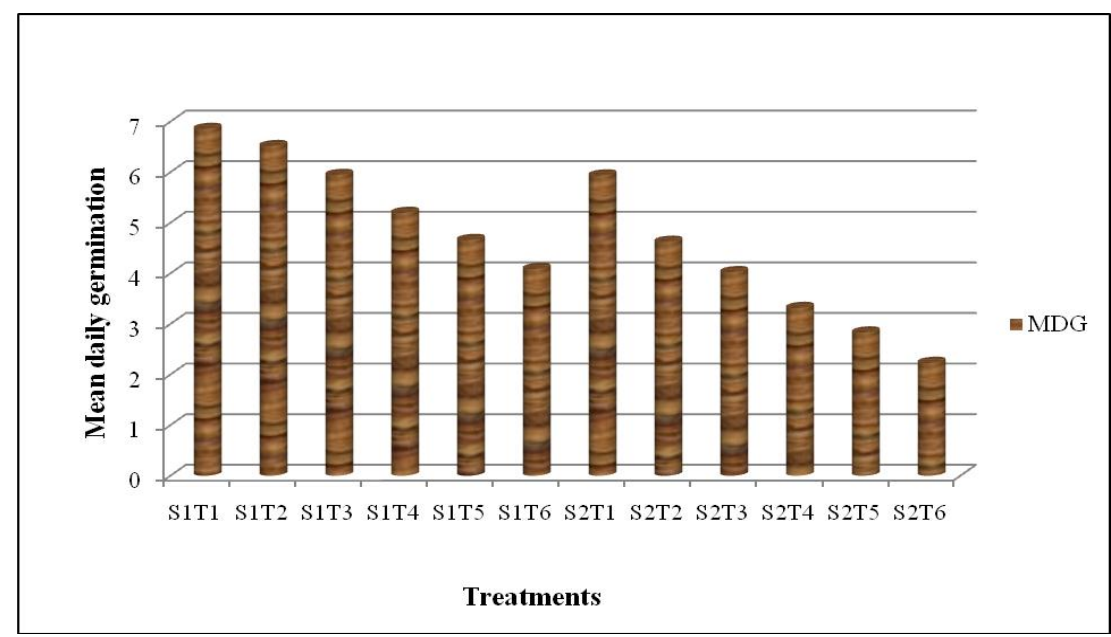

Fig.3 Influence of LCO phytotoxicity of roots and shoots of maize under salt stress

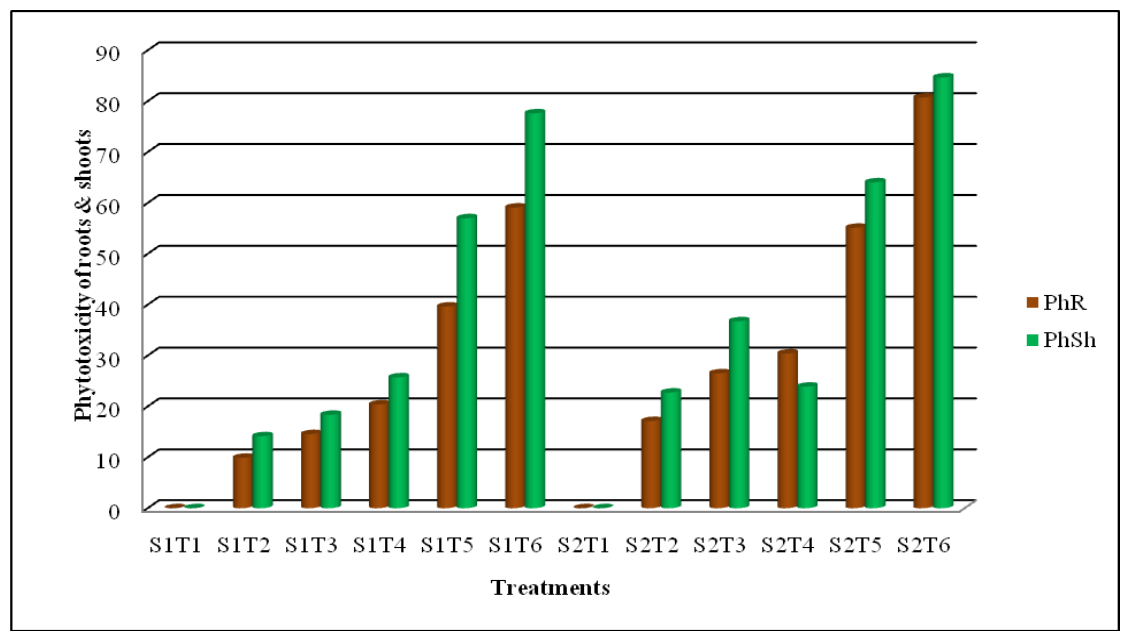

LCO effect was significant on seed germination. The increase in germination over nonprimed seeds accounted for $13,29,32,36$, 39 and 45 per cent under $0,2,4,6,8$ and 10 $\mathrm{dSm}^{-1} \mathrm{NaCl}$ salt concentrations. LCO Primed seeds of maize might have better competency for water absorption from the growing media that enabled metabolic activities in seeds during germination process of a start much earlier than radicle and plumule appearance. Similarly increased solubilization of seed storage proteins like the beta subunit of the globulin and enhanced antioxidative activity in primed seeds facilitated germination.
The salt tolerant cultivars of the crop can be identified on the basis of germination stress tolerance index because during germination, seed vigour and seed storage conditions also affect. However, in the present study, healthy seeds having similar size and good viability were used. So in this case the reduction in germination stress tolerance index may have been due to the effect of salinity. Reason attributed for the retard seed germination and root emergence at higher salinity level might be due to osmotic effect which is deleterious and prevent the plants from maintaining their proper nutritional requirements necessary for 
their healthy growth which led to lesser tolerance for salinity (Krishnamurthy et al., 2007). Results of germination stress tolerance index revealed that the salinity level $2 \mathrm{dS} \mathrm{m}^{-1}$, the LCO primed seeds has 89 of GSTI which is affordable for growing while for salinity level $4 \mathrm{dS} \mathrm{m}^{-1}$ which is close to $2 \mathrm{dS} \mathrm{m}^{-1}$ proved to suitable for cultivation. It is well known fact that if crop stand is good and well established at the initial level then the yield will be higher than that crop with poor stand. Results of Hamid et al., (2008) also confirmed the present findings. The reason for relative increase in GSTI of LCO primed seeds might be due to the osmotic potential acceleration which induces the uptake of water necessary for mobilization of nutrient required for germination.

Daily mean germination act as an indicator for salt tolerance. The reason for higher mean daily germination in control might be due to lack of $\mathrm{NaCl}$ concentration. Range of mean daily germination ranged from 6.86 to 4.09 for priming and 5.94 to 2.23 for non priming for control and $10 \mathrm{dS} \mathrm{m}^{-1}$, respectively. Decrease in germination by increasing of salinity level was possibly due to reduced osmotic potential, high levels of toxic ions and seed food reserve.

Information on phytotoxicity is important to identify the phytotoxicity tolerance of the crop. Increase in $\mathrm{NaCl}$ concentrations increased the phytotoxicity which was supported by the findings of Asmare (2013). High salinity inhibit root and shoot elongation due to slowing down of the water uptake by the crop. However, LCO primed seeds had relatively low phytotoxicity of root and shoot that indicated that, it was better in tolerating higher $\mathrm{NaCl}$ concentration. This may be attributed to earlier germination induced by LCO priming. During priming, the embryo expands and compact's the endosperm and accelerates the activities of hydrolytic enzymes. The compaction force facilitates root and seedling projection after rehydration (Mohammadi, 2009). This might have resulted in vigorous seedlings with more roots and shoot length than the seedlings from non primed seeds. The result of this study is in agreement with Mordi (2013).

This study conclude that the seed priming with lipo chito oligosaccharides (LCO/nod factors) improved the tolerance to salinity at seedling stage of maize by inducing physiological changes in maize. The facts mentioned above make it possible to recommend this LCO seed priming to those plants grown under conditions of soil salinity. Further research is needed to optimize the effectiveness LCO seed priming on number of crops.

\section{References}

Anonymous. 2014. Ministry of Agriculture, 2014-15.

Ashraf, M.Y., Hussain, F., Akhtar, J., Gul, A., Ross, M., and Ebert, G. 2008. Effect of different sources and rates of nitrogen and supra optimal level of potassium fertilization on growth, yield and nutrient. Pak. J. Bot., 40(4): 1521-1531.

Asmare, H.A. 2013. Impact of salinity on tolerance, vigor, and seedling relative water content of haricot bean (Phaseolus vulgaris L.) cultivars. J. Plant Sci., 1(3): 22-27.

Basra, S.M.A., Afzal, I., Rashid, R.A., Hameed, A. 2005. Inducing salt tolerance in wheat by seed vigor enhancement techniques. Int. J. Biot. Biol., 2: 173-179.

Debez, A., Chaibi, W., and Bouzid, S. 2001. Effect du $\mathrm{NaCl}$ et de regulatoeurs de croissance sur la germination d' Atriplex halimus L. Cahiers Agricultures., 10: 135-138.

FAO. 2012. Land and plant nutrition 
management service.

Gomes-Filho, E., Machado Lima, C.R.F., Costa, J.H., Da Silva, A.C., Da Guia Silva Lima, M., Gupta, N.K., Meena, S.K., Gupta, S., Khandelwal, S.K. 2002. Gas exchange, membrane permeability and ion uptake in two species of Indian jujube differing in salt tolerance. Photosynthetica, 40: 535-539.

Hamid, M., Ashraf, M.Y., Rehman, K.U., and Arshad, M. 2008. Influence of salicylic acid seed priming on growth and some biochemical attributes on wheat growth under saline conditions. Pak. J. Bot., 40(1): 361-367.

Khajeh-Hosseini, M., Powell, A.A. and Bimgham, I.J. 2003. The interaction between salinity stress and seed vigor during germination of soybean seeds. Seed Sci. Technol., 31: 715-725.

Khan, A.A. 1992. Preplant physiological seed conditioning. Hort. Rev., 14: 131-181.

Krishnamurthy, L., Serraj, R., Hash, C.T., Dakheel, A.J., and Reddy, B.V.S. 2007.
Screening sorghum genotypes for salinity tolerant biomass production. Euphytica, 156: 15-24.

Mohammadi, G.R. 2009. The Influence of $\mathrm{NaCl}$ priming on seed germination and seedling growth of canola (Brassica napus L.) under salinity conditions. $J$. Agric. Environ. Sci., 5: 696-700.

Mordi, P., and Zavareh, M. 2013. Effects of salinity on germination and early seedling growth of chickpea (Cicer arietinum L.) cultivars. Int. J. Farming and Allied Sci., 2(3): 70-74.

Supanjani, K.D. Lee, H. Duzan and D.L. Smith. 2009. Effect of lipochitooligosaccharide on germination and seedling growth of cauliflower. Jurnal Akta Agrosia, 12(1): 75 - 82.

Zeinali, E., Soltani, A. and Galeshi, S. 2002. Response of germination components to salinity stress in oil seed rape (Brassica napusL.). Iranian J. Agric. Sci., 33: 137-145.

\section{How to cite this article:}

Udhaya Nandhini, D. and Somasundaram, E. 2017. Lipo-Chito Oligosaccharides Enhances Germination Tolerance of Maize to Salinity Stress. Int.J.Curr.Microbiol.App.Sci. 6(3): 437443. doi: https://doi.org/10.20546/ijcmas.2017.603.050 